This work is licensed under a Creative Commons Attribution 4.0 International License.

Ovaj rad dostupan je za upotrebu pod licencom Creative Commons Imenovanje 4.0 međunarodna.

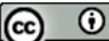

\section{Sara KHAZAI}

Ferdowsi University of Mashhad,

Faculty of Humanities, The English Department

Mashhad. Iran

sarakhazai@hotmail.com

\section{Maryam S. BEYAD}

Faculty of Foreign Languages and Literatures

University of Tehran

Kargare-Shomali Street. Tehran. Iran

msbeyad@ut.ac.ir

\section{Mahmoud R.G. SABBAGH}

Ferdowsi University of Mashhad,

Faculty of Humanities, The English Department

Mashhad. Iran

mrg.sabbagh@um.ac.ir
UDK 821.111-31.09 Bronte,C.=111

$81^{\prime} 42=111$

DOI: 10.29162/ANAFORA.v4i2.1

Izvorni znanstveni članak

Original Research Article

Primljeno 17. kolovoza 2017.

Received: 17 August 2017

Prihvaćeno 14. prosinca 2017. Accepted: 14 December 2017

\title{
SILENCE AND SELF-EXPRESSION
} IN CHARLOTTE BRONTË'S SHIRLEY: AN APPLICATION OF JOHN SEARLE'S SPEECH ACTS THEORY

\begin{abstract}
Despite the "comedic" happy ending of Brontës Shirley (1849), its heroine's taciturn incommunicativeness towards the end of the novel in contrast to her lively former derring-do, has naturally given rise to various speculations about the nature of her transformation. The fact that many of the final exchanges between her and Louis Moore are reported with a temporary shift of point of view in Louis's personal journal, with an obvious artistic distance between the narrator's voice and his, merely serves to cast darker shadows over the veracity of his conclusions. The present appli-
\end{abstract}


cation of Searle's speech acts theory to some dialogue samples from Shirley, focuses on the differences of communicational styles in its heroine at three stages of the narrative and concludes that feeling the weight of the "new world" she has entered after her betrothal, Shirley finds that there is a consequent need for her to employ more expressive speech acts to elucidate, fewer assertives for greater self-effacement, and more frequent hedges to give a softer edge to her directives. Shirley's linguistic technique now relies for its success on her silence and tolerant manner rather than persuasive arguments, and her speech mannerisms might in fact be presumed a "performance." She thus shifts her style of expression intentionally, and in such a fashion as to empower Louis further and hand the conversational reins over to him.

Keywords: Shirley, Charlotte Brontë, discourse analysis, John Searle, speech acts

\section{Introduction}

Although Shirley ends up with a felicitous outcome for its independent and assertive heroine, in the course of the novel, Shirley's personal communicational style seems to undergo significant modifications, and a new kind of taciturn incommunicativeness is attributed to her by other characters as she prepares herself to enter a new relationship with her chosen partner. Considering the oppositional exchanges between her and Louis Moore in the past, naturally, the final question for the reader is who ends up adjusting to whom and whether "silence" has ultimately been settled upon by Shirley as her preferred response. An early exchange between Shirley and Louis Moore evokes a singular, Medusa-style take on the myth of Pygmalion. She declares:

"One man in times of old, it is said, imparted vitality to the statue he had chiselled. Others may have the contrary gift of turning life to stone."

Moore paused on this observation before he replied to it. His look, at once struck and meditative, said,

"A strange phrase: what may it mean?"

He turned it over in his mind, with thought deep and slow, as some German pondering metaphysics.

"You mean," he said, at last, "that some men inspire repugnance, and so chill the kind heart."

"Ingenious!" responded Shirley. "If the interpretation pleases you, you are welcome to hold it valid. I don't care." (411) 
It is possible to conclude that where Robert Moore apparently breathes new life into the rather static and reclusive existence of Caroline Helstone, his brother, Louis, in effect has managed to extinguish the bright light that is Shirley, thus reversing the myth of Pygmalion in the process and "turning life to stone." However, Brontë's narrator enigmatically tells us that Shirley's "abdication" may have been an intentional maneuver:

In all this, Miss Keeldar partly yielded to her disposition; but a remark she made a year afterwards proved that she partly also acted on system. "Louis," she said, "would never have learned to rule, if she had not ceased to govern: the incapacity of the sovereign had developed the powers of the premier." (535)

The present application of Searle's "Speech Acts" theory to selected dialogues in Shirley focuses on the difference in the conversational style of the allegedly voluble Shirley of Vol. II (pre-Louis) versus her much commented-on increasing silence in Vol. III (post-Louis), and investigates the question of whether, instead of the purported introversion, Shirley is in fact employing her speech acts in such a modified fashion as to create a different sort of covert effect in her new alliance.

\subsection{Shirley: Silence, Self-expression, and Interpreting Speeches}

The whole of the first volume of Shirley is, in fact, dedicated to the story of the cousins, Caroline Helstone and Robert Moore. Shirley Keeldar, the eponymous heroine, and Louis Moore, Robert's brother and the male protagonist, are each introduced towards the ends of volumes I and II, respectively. However, despite the fact that the entirety of the narrative follows the comparatively modest exploits of Caroline Helstone, it is the courage and vibrancy of Shirley's personality that breathe life and complexity into an otherwise mundane Victorian tale. The twenty-one-year-old Shirley is an heiress of great beauty, spirit and generosity of heart. The second volume of the book is in fact dominated by her oft-times masculine tackling of her affairs as she becomes involved with the workers' strife, their attack on Robert Moore's industrial machinery, and later his person, the subtle management of local gentry and the clerics, as well as fending off the various fortune hunters that pay her court, while the narrator summarily and blithely tells us that: "In her past were sweet passages; in her future rosy hopes" (195). Harman claims that Shirley demonstrates what "Brontë imagines ... a woman might do if she were a man of public stature," and further 
observes, "[Shirley's] role is both extraordinary in its play of opportunities and limited in its actual powers" (Feminine 23). Susan Gubar says of Shirley: "In spite of her independent activity and exuberant liveliness, [she] seems slightly unreal to most readers and this very unreality serves to remind us that she is part of a fantastic wish-fulfillment, an affirmation of what ought to be possible for women" (11). Janet Freeman further asserts that Caroline in Volume I becomes progressively more isolated from public life and Shirley's entrance breaks "what for eleven chapters has come to look like an unbridgeable gulf between female retirement and male activity" (Unity 570-71).

In her dealings with the opposite sex, Shirley employs none of the usual feminine arts and allurements in fashion, as the narrator approvingly declares: "she was all interest, life, and earnestness: there was nothing coquettish in her demeanour" (211). Shirley exudes self-confidence: "It is my misfortune and habit, I know, to think of myself paramount to anybody else" (205), and displays unique physical courage: "There is a base alloy of moral cowardice in my composition ... I am fearless, physically" (224). She boasts several times that she has no doubt of her equality with men: "I consider myself not unworthy to be the associate of the best of them--of gentlemen, I mean: though that is saying a great deal" (180), and has a keen understanding of what interests them: "I read the leading articles, Joe, and the foreign intelligence, and I look over the market prices: in short, I read just what gentlemen read" (276), and yet she tones her declarations down with sporadic and ambiguous Victorian comments on men like: "Nothing ever charms me more than when I meet my superior-- one who makes me sincerely feel that he is my superior ... the higher above me, so much the better: it degrades to stoop--it is glorious to look up" (184).

Although critics like Lamonica describe Shirley as "a figure of female freedom" (172), she is too elusive a personality to pigeonhole. With the very first descriptions we are warned that despite her features being "mobile" and "speaking," "their changes were not to be understood, nor their language interpreted all at once" (169). As she complains to Caroline:

Men, I believe, fancy women's minds something like those of children. Now, that is a mistake.... If men could see us as we really are, they would be a little amazed; but the cleverest, the acutest men are often under an illusion about women: they do not read them in a true light; they misapprehend them, both for good and evil. (296) 
As Louis Moore, Shirley's former tutor enters and dominates the scene in Volume III, Shirley's exploits appear to become limited to the domestic and courtship issues, and we are eventually informed that she has lapsed into a peculiar kind of incommunicativeness. Miriam Allott has argued that the position of Shirley and her tutor is that of Jane and her master reversed. "Robert and Louis Moore are not quite such social savages, externally, as Mr. Rochester; but in trifling with women's affections they are hardly less harsh or selfish, and they are just as strong in will and giant in limb" (125). Silence, self-expression, and insightful interpretation of others' speeches are topics that come up frequently and significantly in Brontës Shirley and seem to be inextricably linked to feminist questions of dominance and capitulation. To begin with, Shirley makes several cryptic references to herself not wishing, or being able to, communicate the entirety of her reflections or attitudes in conversation:

"I have a great deal to say, if I could get it out in lucid order, which I never can do."

Mr Yorke, instead of replying, gazed at her much puzzled. He could not divine what her look signified; whether she spoke in earnest or in jest: there was purpose and feeling, banter and scoff playing, mingled, on her mobile lineaments.

"I don't understand thee," he said, turning away.

She laughed: "Take courage, sir; you are not singular in your ignorance." (312)

Louis Moore becomes frustrated with her taciturn manner on several occasions and complains:

"You do know, but you won't speak: all must be locked up in yourself."

"Because it is not worth sharing."

"Because nobody can give the high price you require for your confidence.

Nobody is rich enough to purchase it. Nobody has the honour, the intellect, the power you demand in your adviser. There is not a shoulder in England on which you would rest your hand for support." (426-27)

In reaction to his persistence, Shirley tries to explain her conduct: "In fact, I am neither so strong, nor have I such pride in my strength as people think, $\mathrm{Mr}$ Moore; nor am I so regardless of sympathy; but when I have any grief, I fear to impart it to those I love, lest it should pain them; and to those whom I view with 
indifference, I cannot condescend to complain" (428-29). When he insists that she come to him if in need, she confesses that she finds Louis generally hard to approach:

"You will cherish such feelings no more in silence?"

"Not if I dare speak."

"In using the word 'dare, to whom do you allude?"

“To you."

"How is it applicable to me?"

"On account of your austerity and shyness." (429-30)

Louis is persistent in pressurizing her to speak with a sometimes quite dramatic language:

"A minute madam," I said, keeping my hand on the door-handle before I opened it. "We have had a long conversation this morning, but the last word has not been spoken yet: it is yours to speak it."

"May I pass?"

"No. I guard the door. I would almost rather die than let you leave me just now, without speaking the word I demand."

"What dare you expect me to say?"

"What I am dying and perishing to hear; what I must and will hear; what you dare not now suppress." (520)

Elsewhere he declares: "I wish I had the gift of persuasion, and could incline you to speak willingly" (423). Nevertheless, in a paradoxical manner, he tremendously enjoys immobilizing her when he proposes: "She could not hear me speak so, unmoved, and she was moved. It was right--I meant to move her. She could not answer me, nor could she look at me: I should have been sorry if she could have done either" (514). But if Shirley pronounces vows of obedience, her voice is music to his ears:

"I am glad I know my keeper, and am used to him. Only his voice will I follow; only his hand shall manage me; only at his feet will I repose."

I took her back to her seat, and sat down by her side: I wanted to hear her speak again: I could never have enough of her voice and her words. (522) 
Self-expression is extremely important to Louis, and he finds a convenient outlet in the form of his notebook: ". . . none can deprive me of this little book, and, through this pencil, I can say to it what I will--say what I dare utter to nothing living--say what I dare not think aloud" (435), and when he has triumphantly reduced Shirley to absolute silence, he is eager to talk: "Difficult or not, something must be done; something must be said. I could not, and would not, sit silent with all that beauty modestly mute in my presence" (515). The narrator tells us that during their French lessons, in the tutor-pupil setting, Shirley not only repeats Louis parrot-wise but also turns into a mirror-image of him, as she has done in her formative years:

He recited the passage deliberately, accurately, with slow, impressive emphasis. Shirley, by degrees, inclined her ear as he went on. Her face, before turned from him, returned towards him. When he ceased, she took the word up as if from his lips: she took his very tone; she seized his very accent; she delivered the periods as he had delivered them: she reproduced his manner, his pronunciation, his expression. (411)

During the proposal scene at the end of the book, Louis claims: “. . . you whistle the very tunes you imitated from my lips, or sing the very songs you have caught up by ear from my voice" (519). Once everything is settled between them, though, the bride-to-be lapses into silence: "Thus vanquished and restricted, she pined, like any other chained denizen of deserts. Her captor alone could cheer her; his society only could make amends for the lost privilege of liberty: in his absence, she sat or wandered alone; spoke little, and ate less" (534). Yet, she apparently does not speak much to her "captor" either as Louis complains: "She was very silent: I think she never spoke to me" (528). Caroline, too, is frustrated by Shirley's inertness: "Shirley is as naughty as ever, Robert: she will neither say Yes nor No to any question put" (536).

Towards the end of the novel, when Shirley puts off her wedding date time and again and indefinitely, Louis takes her reluctance as a challenge: "Pantheress!-- beautiful forest-born!--wily, tameless, peerless nature! She gnaws her chain: I see the white teeth working at the steel! She has dreams of her wild woods, and pinings after virgin freedom" (527).

Whatever her motivation for postponing her wedding, she is said to have "abdicated" without struggle from managing her own property: "Louis was 
himself obliged to direct all arrangements: he was virtually master of Fieldhead, weeks before he became so nominally" (534).

Louis's impressions of Shirley are shared with the reader through extracts from his personal diary, which present a rather confusing dichotomy. He begins by describing her as a "careless, attractive thing" (435) and "an unsophisticated, untaught thing" (437) with "the modesty of girlhood" as her "halo" (436) and a child in whom "there is always something to chide" (435); yet, at the same time, he glories in his own strength and potential for conquering her fiery temper, comparing her to "a young lioness or leopardess" (439). In one of their conversations, he tells her: "With your powerful mind, you must feel independent of help, of advice, of society," but a few seconds later adds: "You are very nervous and womanish" (426-27). Shirley, naturally, objects: "You complimented me two minutes since on my powerful mind" (427).

To begin with, the thirty-year-old former tutor seems to be pointedly ignored by Shirley. In his notebook confessionals, Louis describes himself alternately as foolish ("the most fatuitous") and "one of the plainest of men," "a dreamer" and "a rapt, romantic lunatic" (436) whose "prosaic composition" has been helplessly inspired into romance by Shirley. He nevertheless boasts of his own "knowledge," "prudence," "calm," and "power" (438), eagerly awaiting occasions where he might guide and correct Shirley as a tutor: "I delight to find her at fault, and were I always resident with her, I am aware she would be no niggard in thus ministering to my enjoyment. She would just give me something to do; to rectify: a theme for my tutor-lectures" (438).

The notebook presents an egotistically self-assertive man who combines a generally self-congratulatory attitude with an impotence incapable of immobilizing Shirley's boundless energy or depriving her of her vitality:

Louis had presaged difficulties, and he had found them: in fact, his mistress had shown herself exquisitely provoking; putting off her marriage day by day, week by week, month by month. At first coaxing him with soft pretences of procrastination, and in the end rousing his whole deliberate but determined nature to revolt against her tyranny, at once so sweet and so intolerable. (534)

While some have concluded that Louis has "curbed" and "bent" Shirley to a state of muteness, it is also profitable to note that when an observer sees her 
much later on, she reports that "Mrs. Louis smiled when she talked: she had a real happy, glad, good-natured look; but she had een [sic] that pierced a body through" (541).

A significant body of critical works has examined the ways Charlotte Brontë has tested and upheld nineteenth-century truisms about womanhood, gender relations, and social intercourse, but not many have investigated how a protagonist like Shirley linguistically employs her personal interpretive skills and adopts individual conversational strategies to handle interactional agency in communication to match the new situation she finds herself in after her betrothal to Louis Moore.

Anne Passel believes that the two couples, Robert-Caroline and Louis-Shirley, are one and the same, and the four characters of Shirley represent "the two sides of man and the two sides of woman," their images "not specific but generic, a Caroline-Shirley marrying one Moore or another." Passel also claims the moral of the story to be promoting the "compatible Victorian marriage," including "interpersonal understanding," "man's respect for woman's abilities," and "woman's worshipful acknowledgment of man as her master and superior" (323-26). Alison Hoddinott, on the other hand, presents the two pairs as representing opposites: "Of the two couples in Shirley," she claims, "one couple illustrates the dangers associated with ... constricted roles; the other offers the possibility of a way out" (166-74).

According to Gilbert and Gubar, the fact “That Shirley is Caroline's double, a projection of all her repressed desire, becomes apparent in the acts she performs 'for' Caroline. What Shirley does is what Caroline would like to do" (382-83). Sarah Gilead initially makes a similar claim: "Shirley first appears as manifestation of Caroline's desire for greater power and freedom. [She] is harbinger of a world where women are allowed to make choices, exert social and personal power, and grow up" (314), but then concludes, "Shirley fails to import value or meaning to the culturally bereft, socially dispossessed Caroline; she fails to transform Caroline or the novel" (316). It has been suggested that what Shirley seeks is "spiritual, intellectual and emotional affinity" (Singh 165). Vanskike points out that inconsistencies in character development, particularly in the case of Shirley Keeldar, have been frequently highlighted by the critics (477), but argues that "Shirley is never presented as a homogenous individual"; therefore, her transformation from independent woman to dependent wife is 
an expression of "ambiguity or ambivalence on the part of Brontë," resulting in Shirley's "paradoxically consistent inconsistency" (478). Kucichdiscusses a pattern of "general reserve" as a "martyring of creative potential," or "deliberate refusals of self-expression" in the narrative (913). The "reversibility of power relations" is "directly a part of the romantic relationship," which he calls "the relations of dominance" (913):

It is primarily a means of heightening an ambiguity in relation to power that is at the heart of each individual character. It becomes clear by examining the personality of Shirley and Louis that every human being is a mixture of dominant and submissive impulses. (933)

Rebecca A. McLaughlin, on the other hand, suggests that marriage and female power are not mutually exclusive. She argues that Shirley's desire for a "master" is jocular, and points out that in the proposal scene Louis's asking Shirley not to "smile" indicates that she is gently mocking him. Moreover, Shirley compares Louis to her dog, a domestic and tamable animal in contrast with herself as a predatory cat. Looking at the French texts recited by Shirley, McLaughlin concludes that rather than being broken in, "the horse learns to control or master its own strength," and the story of the reed and the oak also recommends compromise rather than rigidity (217-22).

Interpreting Shirley's ending with a closer affinity to McLaughlin's arguments on compromise and controlled strength, we shall proceed to identify and examine speech acts for the purpose of giving linguistic support (or not, of course) to prior intuitions about what patterns of usage are most common in particular conversations between the two characters. Although there are only a total of nine conversations between Shirley and Louis, three of them take about/over ten pages each, so much so that the critic Miriam Allott complains of "too-extended dialogue; it does not advance but endlessly retards the development of the story" (135). The lengthy exchanges, however, do provide ample material for discourse analysis.

\subsection{Speech Acts in Charlotte Brontës Shirley}

Leo Spitzer (1887-1960), the German linguist and perhaps the father of literary stylistics, claims that the smallest detail of language can unlock the "soul" of a literary work (qtd. in Leech and Short, Style 2). Cataloguing a character's 
personal linguistic choices eventually illuminates the personalities of both the speaker and the hearer, their intentions, the nuances of their relationship, their understanding of each other's dispositions, and the measure of their authority, sincerity or sensitivity in their interactions.

The basic idea behind the speech act theory is to consider language as a tool for performing actions. When people produce an utterance, they may variously declare, assert, express, promise, complain, apologize, compliment, threaten, refuse, etc. These acts are in the minds of the speakers when uttered, and the listeners need to recognize each act and interpret the meaning thereby conveyed.

When Austin (1962) and Searle (1969) talked about the speech acts, however, they agreed that it had nothing to do with language used in fictive realms. As nobody would believe that a marriage in a play is real, for instance, language used on the stage does not have the power of being performative, and should be excluded from realistic speech acts. Austin, for instance, separates the "standard" promise with deliberate intention from the "impure" promise in a novel, poetry, or the stage, and says that only the standard speech with "consciousness, meaning, presence, truth should be analyzed" (qtd. in Miller 60-87).

Derrida, among others, opposes Austin's notion by pointing out that there are no pure, normal, or standard speech acts. When language has been uttered, the sentence is left free to have new meanings in different contexts (qtd. in Miller 93). Despite the early controversies, the applicability of the theory to literature has led many critics to employ it for literary analysis over the years. For instance, Perelman (1980) has used the speech act theory to investigate Beowulf and link the speech acts a character is permitted to perform to his social status. Roth (1991) has analyzed The Odysseus of Homer in terms of speech acts and intentionality. Schooler (2004) has studied prayers in Chaucer's poetry and found that the words of a prayer alone do not perform the acts, but are influenced by accompanying conditions, like intent, setting, and position. Nishimura's study (2005), "Language, Violence, and Irrevocability: Speech Acts in Tess of the D'Urbervilles" has claimed that this novel is a story about speech acts, and that performatives bring about what they say throughout the narrative. Shoshana Felman has imagined an encounter between Molière's Don Juan and J. L. Austin, and explored the relation between speech and the erotic (1980/2003). Garcia (2008) has tried to show that poetry can incorporate speech acts naturally, and Levinson, likewise, has proposed that every poem begins with a deleted 
performative "I imagine myself in and invite you to conceive of a world in which. ..." (qtd. in Leech, Postulates 88). Rozik (2000) has studied metaphoric speech acts in Ionesco's Exit theKing, and finally, Fontana (2009) has analyzed Dante Rossetti's poetry by focusing on the "Exercitive" speech acts, in which the speakers try to influence others by ordering, urging, advising, or warning.

The conversations brought under discussion by this research fit within the particularly restrictive context of nineteenth-century England with its social mores and accepted norms of conduct in cross-sex discourse, and there were numerous etiquette guides codifying the rules of behavior and speech for women at the time. A famous author mentioned humorously by Jane Austen in Pride and Prejudice (59) was James Fordyce, who warned women against "boundless loquacity" (89). The eighteenth-century Charles Allen advised females against "rambling from one subject to another" (94), and Gregory counseled against "showing men the full extent of your knowledge" (37). Sarah Stickney Ellis in Women of England warns female readers against talking too much of their "pet hobbies," "the commonplace," or speaking "without regard to time, place, or general appropriateness" as well as throwing out "random statements," or monopolizing the conversation (41). According to the conduct writer Chapone (1829), most authors stress the importance of displaying a modest and pleasant demeanor through "respectful and earnest attention" (127). She points out the need for young women to "appear interested in what is said" by asking questions (127).

Speaking in a language, claims John Searle $(1969,1975,1979,1983,2002)$, is a matter of performing "acts" with specific intentions governed by a number of rules (see Grewendorf and Meggle; Searle, "Mind" 4). In Speech Acts: An Essay in the Philosophy of Language, Searle moves beyond Austin's framework and classifies speech acts into five different groups (Mind 5-6):

I claim specifically that there are five, and only five ... basic illocutionary points. These are;

First the assertive. In an assertive speech act, the speaker commits himself in varying degrees to the truth of the expressed proposition. Examples are statements, explanations, and assertions.

The second are directives. In directives the speaker attempts to get the hearer to do something. Examples are orders, requests, and commands. 
The third are commissives. In the commissive speech act the speaker commits himself to doing something, to some future course of action. The most famous example, of course, is promising, but other commissives are vows, threats, pledges, contracts, and guarantees.

The fourth class are expressives. In an expressive speech act, the speaker expresses his feelings and attitudes about some state of affairs specified by the propositional content. Examples are apologies, thanks, and congratulations.

Fifth and finally, there are declarations. In the declaration the speaker brings about changes in the world through his utterances, so the world changes to match the propositional content, solely in virtue of the successful performance of the utterance. Examples are declaring war, pronouncing somebody man and wife, and adjourning a meeting. (My bolds 5)

It is necessary to note here that Searle's "directives" also include what would normally be called "questions" as well as "commands." Moreover, an "indirect speech act" is the kind of utterance in which "one illocutionary act is performed indirectly by way of performing another" (Searle, "Indirect S.A." 60). A further distinction between "Illocution" and "Perlocution" is also made by Searle: "We typically do not talk simply with the intention of producing understanding . . . - the illocutionary effect. The principle, intended effect or point of my saying something is perlocutionary" (qtd. in Rust 120).

Speakers can help their hearers through Searle's Principle of Expressibility, or "Spelling it out" (19). What the principle says is that we can analyze speech acts by restating what is said so that it now coincides with what is meant (qtd. in Fotion 25-40). Furthermore, in "A Taxonomy of Illucutionary Acts" (see Searle, "Experience and Meaning" 1-29), Searle offers an improved classification resting on a distinction between two directions of fit between language and reality, from word (mind) to world, on the one hand, and from world to word (mind), on the other. Some utterances have no direction of fit and some have a dual direction of fit. Searle proposes twelve dimensions that create differences in illocutionary acts. These differences relate to the:

1. Point or purpose of an act

2. Direction of fit (important in declarations)

3. Expressed psychological state 
4. Force or strength of the point (important in commissives/ assertives/ directives/ expressives)

5. Status or position of the hearer or speaker (important in directives/ declaratives)

6. The way the utterance relates to the interests of the hearer or speaker (important in assertives/expressives)

7. The relationship to the rest of the discourse (important in assertives)

8. Propositional content (important in expressives)

9. Requirement that some acts must be speech acts while others need not be (e.g. classifying/concluding need not while promising/declaring/directing have to be)

10. Lack of or need for extra-linguistic institutions (important in commissives/declaratives)

11. Lack of or need for illocutionary verbs (important in assertives)

12. Style of performance. (see Searle, "Experience and Meaning" 2-8)

To make a comparison of how Shirley conducts herself verbally with Louis as their relationship develops from its early stages to their engagement, and how she changes her tactics in manipulating speech acts in her encounters with him, three important scenes from the novel have been selected.

\section{I.}

In the first scene (423-24), Shirley has been acting quite strangely for a few days and her young cousin, Henry has just reported to Louis that Shirley visited her lawyers and made a will. Alarmed by the news, Louis sends for her and determines to discover what troubles her. Despite the fact that Louis has the advantage of age over Shirley and perhaps some claim to deference as her former tutor, he starts off the topic he wishes to discuss apologetically and with much trepidation: "The subject I would broach is one of some moment: perhaps I have hardly a right to approach it: it is possible I ought to frame an apology: it is possible no apology can excuse me." Louis has to repeat his directive (i.e. request) for Shirley to be seated in different ways, employing the Principle of Expressibility (further elucidation) to try and gather some momentum as she seems to be standing by the doorframe ready to take flight with her sewing in hand: "Be seated first. The subject I would broach is one of some moment... W Will you sit down? Formerly, Miss Keeldar, I had some influence with you" (423). Regard- 
less of Louis's tentative questions, Shirley at first refuses to provide him with any clear, direct responses. Instead, with a noticeable ring of authority, she politely, but firmly, tries to shift the discussion of her own health to other subjects, and counters most of Louis's directives with directive speech acts of her own: "Let me read some French, Mr. Moore, or I will even take a spell at the Latin grammar, and let us proclaim a truce to all sanitary discussions" (423). When Louis again tries to persist with: "No--no: it is time there were discussions" (423), she brusquely retorts: "Discuss away, then, but do not choose me for your text" (423). Louis persists in pursuing the interrogation and she firmly declares: "Mr. Moore, we will pause here. . . Now, talk of something else. What wet weather we have!" (424). While the performance style of Louis's assertive speech acts is too hesitant to carry much force, Shirley delivers her speech acts with much conviction and resolve and clearly signals her dissatisfaction with the topic at hand: "I have neither cough, pain, nor fever." In response to Louis's questions about her lack of appetite, restless sleep and weight loss, she stubbornly gives him the exact same assertive three times: “. . . it is not because I am ill” (424). Although expressive speech acts (expressing feelings/opinions) as a rule lack a direction of fit (word to world or vice versa) and do not have to convince the other party of the exchange of their truth value, Shirley's are inextricably related to her assertives and are meant to carry a good measure of conviction as they also act as indirect assertives: "I am a healthy subject," "I say I am well." And in response to Louis's observation that she is changed, she relies: "That matters to none but myself" (423). To get rid of his probing conclusions - "there is a nervous alarm in your eye--a nervous disquiet in your manner" - she cuts him off with: "You have exactly hit it: I am nervous" (424).

As we turn to the next two scenes, it would be beneficial to keep in mind how well Shirley manages to control the boundaries of early exchanges between herself and Louis. Her assertives and expressives are pronounced unequivocally and with composure. She handles Louis's directives confidently and, instead of complying, fires off some directives of her own in response. Of Searle's twelve dimensions, the one strongly at work in this exchange is obviously the fifth one, i.e. the relative statuses of the speakers. Apart from the politeness strategies employed at the time, Louis, the impoverished tutor, is not at liberty to put much force behind his directives to Shirley, the flamboyant heiress, which consequently affects his style of performance (dimension twelve) to a great extent. 
II.

In the second scene (517-19), Louis describes his successful proposal of marriage to Shirley in his notebook. The temporary shift of narrator naturally means that the telling would be colored by Louis's interpretation of Shirley's performance. Thus, it is even more useful to concentrate on the words uttered directly by her rather than Louis's accompanying commentary. Over forty percent of Shirley's speeches in this exchange are of the expressive type, though her style of delivery (dimension twelve) is far less cool and composed, as indicated by the number of exclamation marks attached to her comments, adding ironic emphasis to each (dimension four, force or strength of the point). She uses quite a number of assertives to describe her suitor, Sir Philip's, rank, and age as compared to her own:

"A beautiful sentence!" .. "Unjust barbarian! ... I hate it. ..."

"I absolutely shudder at the sight of metre or at the sound of rhyme, whenever I am at the Priory or Sir Philip at Fieldhead. Harmony, indeed!” . . "'Leading and improving! teaching and tutoring! bearing and forbearing!' Pah! But it is like a tutor to talk of the 'satisfaction of teaching'-- I suppose you think it the finest employment in the world. I don't-- I reject it. Improving a husband!" (518)

To suggest the unsuitability of a match to Sir Philip, she makes several allusions to the Holy Bible. The Bible, of course, provides Shirley with an extra-linguistic institution for backing up her claims (dimension ten), and the worldto-word direction of fit (referencing her claim to factual outside evidence), and supports the strength of her comments from a moral and secular perspective. Nevertheless, now that he is no longer concerned about her acceptance of the rival suitor, Louis does not seem to take her arguments seriously, and his brief responses are tinged with mild irony.

Shirley's directives are the second most frequent speech act she uses here, and they are mainly queries. Her leading questions also invite Louis to further explain his meaning, discuss his observations, and share his conclusions with her, which is in obvious contrast with the previous scene, where she wished to put a stop to the discussion. Despite her ire and agitation, she uses several hedges (underlined below) that add a softer edge to her directives, making the only forthright instance of a directive, the speech act "Tell me" (Searle's dimen- 
sion four, force or strength of the point). At this point, the decreasing force in Shirley's directives can indicate a shift in the relative statuses of the two characters, assigning greater power to Louis:

"Did you think I should take him?" ... “On what grounds, may I ask?” . .. "Let us take it to pieces. ... compare my grange with his palace, if you please. ..." "'Contrast of temper.-- Mild and amiable, is he: I-—what? Tell me." ... "What do you mean by that, Mr. Moore?" (517-18)

To sum up, Shirley is now much more voluble and forthcoming, but, at the same time, her different performance of the speech acts clearly stems from her agitation. It is also best to keep in mind that Louis's calm, superior manner in comparison to that of Shirley is reported by himself. Joseph Dupras, who performs a deconstructive reading of Shirley, goes so far as to argue that the submissive Shirley does not exist before Louis writes her in his diary (302). Louis meditates in the same scene: "I was unwise to quit my sheet-anchor of calm even for an instant: it deprived me of an advantage and transferred it to her" (517). Furthermore, as far as prescribed female manners for Victorian proposal scenes go, this particular exchange is quite unorthodox. Instead of receiving the male protagonists' declarations with bashful modesty, awe, or proper decorum, and not contributing much to the conversation, as recommended by current conduct books, Shirley dominates this dialogue by her thirty-nine turns against Louis' much more brief and controlled fifteen. Thus not taking Louis's report at face value, the analysis of the speech patterns provides a contrary conclusion for this important exchange. Where Louis thinks he is in control, it is actually Shirley's speech acts that dominate the situation: "She charmed me in this mood: waxing disdainful, half insulting, pride, temper, derision, blent in her large fine eye, that had, just now, the look of a merlin's" (516). In reading the tone of the above encounter, Elizabeth Gargano emphasizes the element of "mutual aggression, as well as the spiky humor underlying all the intense earnestness ... [two parties] 'vie[ing] for mastery"' (799).

III.

In the third scene (528-29), near the conclusion of the novel, a conversation about Shirley's delay in settling a wedding date is again narrated by Louis rather than the omniscient narrative voice of the rest of the book. This last reported dialogue between the main characters has Shirley making twenty-one rather brief 
speech acts against Louis' thirty-one. She employs only one directive to ask a question at the very beginning of the exchange: "Why?" (to resist Louis request for an interview), and is not at all eager to encourage his further explanations of his thoughts or feelings as she did in the previous scene. Her only other remaining directives are pleas for his cooperation: "rise," "Be reasonable, Louis, -- be patient!" (529).

Over sixty percent of Shirley's acts here are of the expressive type, and her only assertives include "the hall is too cold" and "But I shiver" (528), which in fact can be taken as indirect speech acts serving as further expressives to indicate her reluctance to stay and chat. The expressives employed by Shirley all seem straightforward descriptions of her feelings, such as "I have no wish to be cruel" (528), "I am cordial" (529), "No, -- quite calm, and afraid of nothing" (529), and "I like you because you are patient" (529). The trouble with taking these statements at face value is that the accompanying observations by Louis seem to contradict them: "there was softness in her whole deportment, -- in her face, in her voice; but there was also reserve" (528), "hovering aloof like a white shadow" (529), and finally: "She breathed a murmur, inarticulate yet expressive; darted ... and I lost her" (529).

Several of Searle's dimensions might be helpful in analyzing Shirley's expressives here, such as the point or purpose of her act, her expressed psychological state, the force of her points, the statuses of the two parties, and her style of performance. Her short-term purpose, for instance, appears to be mollifying and appeasing Louis for the time being so he would stop pressurizing her for a wedding date, but the shift from strong directives to the weak and the decreased frequency of assertives let her expressives shine through, gather momentum, and convey her long-term intention of greater self-expression at the expense of authoritative or factual speeches (via directive and assertive speech acts). The perlocutionary effect (i.e. point or purpose) of her expressives is not achieved, however, as Louis responds with the forceful directives: "fix our marriage-day. Think of it to-night, and decide" (529). It appears that her style of performance has shifted their relative statuses in such a fashion as to empower Louis to authoritatively try and bring her to the point. One should mark that the directive dominates Louis's speech acts in this scene by nearly fifty percent as he rather peremptorily orders Shirley to: "stay one instant!" (528), "Do not--do not pass!--" (528), "Be cordial to Louis ... approach him,--let him approach" (529). 
Though the commissive speech act is not a favorite with Louis, and there is just one instance of his use of it in scene one, Shirley occasionally employs it to make a future commitment as when in the second conversation she vows: "My husband is not to be my baby. I am not to set him his daily lesson and see that he learns it, and give him a sugarplum if he is good, and a patient, pensive, pathetic lecture if he is bad. .. . I shall insist upon my husband improving me, or else we part" (518). She also announces that she means to taunt Louis with "any defect of which" he is "painfully conscious" (519). In conversation three she exclaims: "... any change will be for the worse!" (529).

Notwithstanding Louis's claim at the outset of this exchange that Shirley "was very silent: I think she never spoke to me" (528), and his conclusion at the end of it that "She breathed a murmur, inarticulate yet expressive" (529), Shirley does use the Principle of Expressibility to clarify her intended illocution several times if only Louis were perceptive enough to notice it. When he accuses Shirley: "I am addressed as Mr. Moore, and Sir; your lips have forgotten Louis" (528), Shirley objects: "No, Louis, no," and elucidates: “. . . it is an easy, liquid name; not soon forgotten" (528). Again, as Louis claims that she is afraid of him, she once more elaborates her response: "You see I am in a new world, Mr. Moore. I don't know myself, -- I don't know you" (529). Finally, when Louis bends a knee to the flags at her feet, she feels the need to explain the reason for her impositive directive to him: “. . . rise; when you do so, I feel troubled and disturbed" (529).

When reminiscing over Shirley's youthful misadventures with Harry and Shirley, Louis voiced a warning that appearances could be quite deceptive where Shirley was concerned: "I see her, and humble enough; but I would neither advise Harry, nor others, to believe too implicitly in the humility which one moment can hide its blushing face like a modest little child, and the next lift it pale and lofty as a marble Juno" (411).

\section{Some Concluding Remarks}

Gender-related variations in language use are context-sensitive and multi-faceted, and negative communicational outcomes, including not only apparent conflict between the characters but also the man's misperceptions of the woman's abilities and intentions, stem from differences in their habits and assumptions about how to participate in conversation. "Ways of talking and behaving that are associated with gender are a matter not of identity but of display;" 
asserts Deborah Tannen, "in other words, the behavior is not a reflection of the individual's nature (identity) but rather of some performance that the individual is accomplishing (display)" (198). The way a character behaves as a listener is obviously as important as his/her role as a speaker in reflecting the quality of the character's mind. More often than not, one's conversational behaviour as a listener also accounts for one's mistakes. A tactical error in communicational politeness in a character, for instance, is to keep talking without listening to one's addressee or transparently not caring about what has just been said. Examples include Louis's persistence in pursuing the topics Shirley wishes to avoid in the first and third dialogues. Although, obviously, he is not an extreme case, in several instances he is very likely to immediately interpret Shirley's statements based on his own misconceptions.

The final performances of all four female characters seem to be overshadowed by their concern with maintaining the hard-won peace with the men and this impedes their freedom of behavior. In several cases, the heroine tries to convey important or sensitive information but is faced with the void of the listener's indifference and inattentiveness highlighted by the dispreferred responses the study has marked. Non-listening, selective listening, and parallel monologues do occur in most of the samples discussed here. In Shirley's last scene, when Shirley confesses with feeling: "You see I am in a new world, Mr. Moore. I don't know myself, -- I don't know you" (529), the dispreferred reply she receives is Moore's parallel monologue of "Now, Shirley ... you can conceive I am far from happy in my present uncertain, unsettled state" (529). In each case, what has been set in denial has risen to the surface at great cost, and then sunk again because the listeners were unable or unwilling to see or hear it. ${ }^{1}$

The marked difference between the depictions of Shirley by the narrator versus that of Louis may legitimately cast shadows of doubt over the veracity of the latter. Both the proposal scene and the final exchange discussed above are reported in Louis's notebook where Charlotte Brontë creates an artistic distance between the narrator's voice and his. Louis's, and many other characters', misperceptions of Shirley's intentions and silences, at the end, stem from a misinterpretation of her new performance. 
Shirley's communicational technique after her betrothal relies for its success on her quietness and patient manner rather than any number of persuasive arguments and protestations. Going back to an earlier quote in this paper, Shirley has in effect now adopted Louis's earlier mannerisms of quiet patience to perfection: “. . . she took his very tone; she seized his very accent; she delivered the periods as he had delivered them: she reproduced his manner, his pronunciation, his expression" (411). To the reader, Shirley's performance conveys the impression that, as she feels the weight of the "new world" she has entered, she finds that there is a consequent need for her to employ several expressive speech acts where fewer would have sufficed in communicating with her betrothed. Thus, the obvious quality of awkwardness in the couple's interactions, which is not resolved but intensified by their engagement, inclines Shirley to use a more than common number of hedges and explanatory speeches, or lapse into lengthy silences where the management of daily affairs is concerned, in her mission to infuse Louis with as much importance and responsibility as she can. This results in a change in their styles of performance and several shifts in Louis's speech mannerism (for the better in his own evaluation at least), where for instance, his hesitant directives at the beginning become replaced with ironic questioning directives in the middle, and the authoritative impositive speech acts at the end of the novel. At the same time, Shirley resorts to using hedges to give a softer edge to her directives in the second conversation and feels the need to elaborate her feelings instead of using her once customary number of directives and assertives. The significant quote used at the outset of this paper - Shirley's confession that Louis "would never have learned to rule, if she had not ceased to govern" (535), speaks of more than merely his authority in practical matters of their daily lives; metaphorically, it also implies her intentionally handing the conversational reins over to Louis as well.

\section{Works Cited}

Allen, Charles. The Polite Lady; Or, a Course of Female Education: In a Series of Letters, from a Mother to Her Daughter. $1^{\text {st }}$ American ed., Philadelphia / Printed for Mathew Carey, 1798.

Allott, Miriam. The Brontes. Routledge, 1974.

Austen, J. Pride and Prejudice. 1813. Wordsworth Classics, 1993.

Brontë, Charlotte. Shirley. 1849. Oxford UP, 2007.

Chapone, Hester. Letters on the Improvement of the Mind. John Sharpe, 1829. 
Dupras, Joseph A. “Charlotte Brontës Shirley and Interpretive Engendering." Papers on Language and Literature, vol. 24, vol. 3, 1988, pp. 301-16.

Ellis, Sarah Stickney. TheWomen of England, Their Social Duties and Domestic Habits. Fisher, Son \& Co., 1839.

Felman, Shoshana. The Scandal of the Speaking Body: Don Juan with J. L. Austin, or Seduction in Two Languages. Stanford UP, 2002.

Fontana, E. "Exercitive Speech Acts in the Poetry of Dante Gabriel Rossetti." Victorian Poetry, vol. 47, 2009, pp. 449-58.

Fotion, Nick. John Searle. Acumen, 2000.

Freeman, Janet. "Unity and Diversity in Shirley." Journal of English and Germanic Philology, vol. 87, 1988, pp. 558-75.

Garcia, L. "Speech Acts and Poetry." International Journal of Philosophy, vol. 37, 2008, pp. 192-205.

Gargano, Elizabeth. “The Education of Brontë's NewNouvelle Héloïse in Shirley." SEL: Studies in English Literature, 1500-1900, vol. 44, 2004, pp. 779-803.

Gilbert, Sandra M., and Susan Gubar. The Madwoman in the Attic: The Woman Writer and the Nineteenth-Century Literary Imagination. $2^{\text {nd }}$ ed, Yale UP, 2000.

Gilead, Sarah. "Liminality and Antiliminality in Charlotte Brontës Novels: Shirley Reads Jane Eyre." Texas Studies in Literature and Language, vol. 29, 1987, pp. 302-22.

Gregory, John. A Father's Legacy to His Daughters. 1774. Garland, 1974.

Grewendorf, Günther, and G. Meggle, editors. Speech Acts, Mind, and Social Reality: Discussions with John R. Searle. Kluwer Academic Publishers, 2002.

Gubar, Susan. “The Genesis of Hunger, According to 'Shirley”” Feminist Studies, vol. 3, no. 3-4, 1976, pp. 5-21.

Harman, Barbara Leah. The Feminine Political Novel in Victorian England. UP of Virginia, 1998.

Hoddinott, Alison. “The Endings of Charlotte Brontës Novels.” Brontë Studies, vol.41, no. 2, 2016, pp. 166-174.

McLaughlin, Rebecca A. "I Prefer a Master: Female Power in Charlotte Brontës Shirley." Brontë Studies, vol. 29, no. 3, 2004, pp. 217-22.

Kucich, John. "Passionate Reserve and Reserved Passion in the Works of Charlotte Bronte." ELH, vol. 52, no. 4, 1985, pp. 913-37.

Lamonica, D. "We Are Three Sisters": Self and Family in the Writing of the Brontës. U of Missouri P, 2003.

Leech, G. "A Set of Postulates." Pragmatics Critical Concept. , edited by Asa Kasher, Routledge. 1998, pp. 87-113.

Leech, G., and M. Short. Style in Fiction: A Linguistic Introduction to English Fictional Prose Foreign Language. Teaching and Research Press, 2001.

Miller, J.H. Speech Acts in Literature. Stanford UP, 2001. 
Nishimura, S. Language, Violence, and Irrevocability: Speech Acts in Tess of the d'Urbervilles. Farminton Hills, 2005.

Passel, Anne W. “The Three Voices in Charlotte Brontë’s Shirley." Brontë Society Transactions, vol. 15 , no. 4, 1969, pp. 323-26.

Perelman, L.C. The Conditions, Consequences, and Structure of Direct Discourse in Beowulf: A Study of Speech Acts. U of Massachusetts P, 1980.

Roth, J.W. Speech Acts and the Poetics of Manhood: The "Lies" of Odysseus. New York UP, 1991.

Rozik, E. “Speech Act Metaphor in Theatre." Journal of Pragmatics, no. 32, 2000, pp. 203-18.

Rust, Joshua, editor. John Searle, Continuum International, 2009.

Schooler, V.D. Prayer in Chaucer's Poetry. U of Florida P, 2004.

Searle, J. Indirect Speech Acts. Syntax and Semantics, vol.3: Speech Acts, edited by P. Cole and Jerry L. Morgan. Academic Press, 1975, pp. 59-82.

---. Speech Acts: An Essay in the Philosophy of Language. Cambridge UP, 1969.

---. "Experience and Meaning: Studies in the Theory of Speech Acts."Language, Mind and Knowledge, Minnesota Studies in the Philosophy of Science VII, edited by K. Gunderson, U of Minnesota P, 1975, pp. 344-69.

Singh, S.N. Charlotte Bronte: A Thematic Study of Her Novels. Mittal Publications, 1987.

Tannen, Deborah. Talking from 9 to 5: Women and Men in the Workplace: Language, Sex and Power. Avon, 1994.

Vanskike, Elliott. "Consistent Inconsistencies: The Transvestite Actress Madame Vestris and Charlotte Bronte's Shirley.” Nineteenth-Century Literature, vol.50, 1996, pp. 464-88. 


\title{
ŠUTNJA I SAMOIZRAŽAVANJE U ROMANU \\ CHARLOTTE BRONTË SHIRLEY: PRIMJENA TEORIJE GOVORNIH ČINOVA JOHNA SEARLEA
}

\section{Sažetak}

\author{
Sara KHAZAI \\ Faculty of Humanities \\ Ferdowsi University of Mashhad \\ Mashhad, Iran \\ sarakhazai@hotmail.com
}

Maryam S. BEYAD

Faculty of Foreign Languages and Literatures

University of Tehran

Kargare-Shomali Street. Tehran. Iran

msbeyad@ut.ac.ir

\section{Mahmoud R. G. SABBAGH}

Faculty of Humanities

Ferdowsi University of Mashhad

Mashhad, Iran

mrg.sabbagh@um.ac.ir

Unatoč sretnom završetku romana Charlotte Brontë Shirley (1849.), vidna suzdržanost i nekomunikativnost junakinje pri kraju romana, suprotna njezinoj ranijoj naglašenoj smjelosti, potaknula je razna nagađanja o prirodi njezine transformacije. Činjenica da su mnogi od posljednjih razgovora između nje i Louisa Moorea priopćeni kroz privremeni pomak narativne perspektive u Louisov osobni dnevnik, s očitom umjetničkom distancom između glasa pripovjedača i Louisova glasa, baca još veću sumnju u vjerodostojnost Louisovih zaključaka. Primjenjujući Searleove teorije govornih činova na nekoliko uzoraka dijaloga iz romana Shirley, ovaj se rad usredotočuje na razlike u komunikacijskim stilovima junakinje u tri faze fabule te ustanovljuje da kroz osjećaj tereta „novog svijeta“, u koji je ušla nakon zaruka, Shirley uviđa nužnost upotrebe izražajnijih govornih činova da bi bila shvaćena, neizricanja vlastitih stavova da bi se što manje isticala te češće uporabe oznaka ograđivanja da bi ublažila oštrinu svojih naredbi. Uspjeh 
junakinjine lingvističke tehnike sada proizlazi iz njezine nečujnosti i tolerantnog stava, a ne uvjerljive argumentacije, a njezini bi se govorni manirizmi zapravo mogli smatrati „predstavom“. Ona, dakle, namjerno mijenja svoj stil izražavanja, i to na takav način da dodatno osnažuje Louisa, omogućivši mu da preuzme glavnu riječ.

Ključne riječi: Shirley, Charlotte Brontë, analiza diskursa, John Searle, govorni činovi 